\title{
DEZINFEKCIJOS POVEIKIS DANTŲ ATSPAUDŲ IR PAGAMINTŲ DANTŲ PROTEZŲ MIKROBINEI TARŠAI
}

\author{
Emilė Pliuščikaitė, Albina Vaičiulevičienė, Inga Vasilavičiūtė, Daiva Mačiulienė \\ Kauno kolegijos Medicinos fakultetas
}

Raktažodžiai: dezinfekuojančios priemonès, dantų atspaudai, protezai, mikroorganizmai, rankų higiena, $\mathrm{HN}$ (higienos norma).

\section{Santrauka}

Bakterijos ir mikroorganizmai ne tik egzistuoja žmoniu aplinkoje ir buityje. Kai kurie patogenai gyvena žmogaus organizme. Žmogus neišvengia kasdienio sąlyčio su mikroorganizmais, kurie iš aplinkos patenka ant rūbų, rankų, odos, plaukų, ne išimtis ir burnos ertmè. Tyrimo tikslas - ivvertinti dezinfekcijos poveiki dantų atspaudų ir dantų technikų pagamintų dantų protezų mikrobinei taršai. Burnos ertmės užterštumo būklę lemia ne tik aplinkos veiksniai, bet asmenine ir burnos higiena, paveldimumas, bendroji sveikatos būklè. Dẻl prastos burnos ertmès higienos, bakterijų ir mikroorganizmų kiekis nekontroliuojamai auga. Planuojant protezavimą, neįmanoma apsieiti be alginatinių ar silikoninių atspaudų. Visa tai, kas buvo paciento burnoje, gali užteršti atspaudą, kuris yra pagrindinis dantų techniko ịrankis. Ši mikroorganizmų plitimo grandinè tarp paciento, odontologo ir dantu techniko vadinama kryžminio užteršimo pavojumi [7].

\section{Ivadas}

Šiandieniniame pasaulyje yra nesuskaičiuojama galybė ligų ir dar daugiau galimybių jomis užsikrèsti. Kiekvieną dieną susiduriame su ịvairiomis bakterijomis ir patogenais, kurie yra pavojingi žmogaus organizmui ir gali sukelti susirgimus. Bakterijos ir mikroorganizmai ne tik egzistuoja mūsų aplinkoje ir buityje, kai kurie patogenai gyvena žmogaus organizme. Žmogus neišvengia kasdienio sąlyčio su mikroorganizmais, kurie iš aplinkos patenka ant rūbų, rankų, odos, plauku, ne išimtis ir burnos ertmè.

Burnos ertmès užterštumo būklę lemia ne tik aplinkos veiksniai, bet asmeninè ir burnos higiena, paveldimumas, bendra sveikatos būklè. Dèl prastos burnos ertmès higienos, bakterijų ir mikroorganizmų kiekis nekontroliuojamai auga. Tai gali lemti prasto burnos kvapo atsiradimą, estetinio vaizdo praradimą, dantys tampa gelsvi, ar net rusvi, pradeda kauptis minkštosios apnašos, kurios ilgainiui tampa kietosiomis (akmenimis). Nesilankant pas specialistus ir nepašalinus susidariusių apnašų, dantenos ima kraujuoti. Tai pirmasis dantenų uždegimo - gingivito požymis. Ilgainiui gingivitas išsivysto ị periodontitą ir galiausiai - i parodontozę, kuri lemia dantų praradimą. Parodontozę sukelia ịvairios bakterijos, kurios kaupiasi dantų apnašose ir kietuosiuose akmenyse [3].

Dažnai net nesusimąstome, kiek daug bakterijų gyvena burnos ertmeje. Planuojant protezavimą, naudojami alginatiniai arba silikoniniai atspaudai. Mikroorganizmai, aptinkami paciento burnoje, gali užteršti atspaudą, kuris yra pirminis ir pagrindinis objektas, kurị naudoja dantų technikas, gamindamas protezus ir kt. Padarius atspaudus ir jų nedezinfekavus, mikroorganizmai iš paciento burnos pateks ant odontologo rankų (pirštinių). Seilèmis užkrèstas nedezinfekuotas atspaudas patenka ị dantų technikų laboratoriją, o vèliau grịžta nedezinfekuotas, užterštas mikroorganizmais nuo dantų techniko rankų. Taip susidaro kryžminio užsikrètimo grandinè ir mikroorganizmai plinta aplinkoje [6]. Gydytojas odontologas dažnai kartu dirba su asistentais, kartais, atliekant operacijas, reikalingos anesteziologo paslaugos, todèl mikroorganizmų plitimo ir užsikrètimo pavojus didèja. Lygiai taip pat užsikrètimo pavojus išlieka ir dantų technikų laboratorijoje. Patekus nedezinfekuotiems atspaudams ị dantų technologijų laboratoriją, mikroorganizmai gali plisti ant darbo stalo paviršiaus, darbo įrankių, dantų techniko rankų.

Lietuvos higienos norma HN 47-1:2020 (HN 47-1:2020) nustato sveikatos priežiūros ịstaigų infekcijų kontrolès reikalavimus. Dantų technikos laboratorijoms privalomas higienos normos XXII skyrius „Dantų technikos laboratorijų infekcijų kontrolès reikalavimai“" [1], kuriame nustatyti privalomieji infekcijų kontrolès reikalavimai Dantų technikos laboratorijų darbo aplinkai ir darbuotojams. Dantų technikai ir gydytojai odontologai privalo laikytis rankų higienos procedūros ir užtikrinti, kad klinikoje padaryti dantų atspaudai ir laboratorijoje pagaminti dantų protezai yra dezinfekuoti ir saugūs. Dantų technikos laboratorijos gaminius būtina dezinfekuoti, 
supakuoti i vienkartines pakuotes ir paženklinti, kaip reikalaujama HN 47-1:2020.

Tyrimo tikslas - ivvertinti dezinfekcijos poveikị dantų atspaudų ir dantų technikų pagamintų dantų protezų mikrobinei taršai.

\section{Tyrimo objektas, medžiaga ir metodai}

Tyrimo objektas - dantų atspaudų ir pagamintų dantų protezų mikrobinè tarša. Atlikta mokslinès ir profesinès literatūros analizé, nagrinejjant burnos mikrobiotą ir veiksnius, turinčius įtakos atspaudų ir dantų techniko darbų mikrobinei taršai. Kokybinès mikrobiologijos tyrimu siekta išsiaiškinti nedezinfekuotų ir dezinfekuotų dantų atspaudų, pagamintų dezinfekuotų ir nedezinfekuotų dantų protezų mikrobinę taršą. Dantų atspaudų ir pagaminto dantų protezo mikrobinès taršos tyrimas atliktas vadovaujantis LST EN ISO 14698 - „1 „Švarūs kambariai ir su jais susijusi kontroliuojamoji aplinka. Biotaršos kontrolè. Bendrieji principai ir metodai“. Šis standartas nustato paviršių mikrobiologinio tyrimo plovinių tvarkos reikalavimus. Tyrimui atlikti ėminiai imti plovinių metodu. Odontologijos klinikoje, suderinus su klinikos vadovu, èminiai imti nuo šešių nedezinfekuotų atspaudų, kuriuos pateikè gydytojas odontologas, po to nuo tų pačių dezinfekuotų šešių atspaudų. Atspaudai pristatyti ị Odontologijos kliniką aptarnaujančią dantų technikos labo- ratoriją. Ploviniai imti nuo iš atspaudų pagamintų protezų prieš jų dezinfekciją ir nuo tų pačių pagamintų protezų po dezinfekcijos. Buvo tiriamas ir lyginamas mikrobinis užterštumas: nedezinfekuotų atspaudų ir po dezinfekcijos; dantų techniko pagamintų nedezinfekuotu protezu ir po dezinfekcijos. Nedezinfekuotų atspaudų ploviniai buvo imami odontologijos klinikoje, tik išèmus atspaudą iš paciento burnos, po to ploviniai imti atlikus atspaudo dezinfekciją odontologijos klinikoje. Pakartotinè dezinfekcija atlikta dantų technikos laboratorijoje ir paimti ploviniai nuo dezinfekuoto atspaudo. Dar buvo imami ploviniai nuo pagamintų dantų protezų: nedezinfekuotų ir dezinfekuotų. Tiek odontologijos klinikoje, tiek dantų technikos laboratorijoje buvo taikoma panardinimo dezinfekcija, naudojant „PrintoSept“, kuriame atspaudai ir pagaminti protezai buvo palaikomi 5 min., kaip nurodè gamintojas, o po dezinfekcijos plaunami po tekančiu vandeniu.

Tyrimas buvo atliktas Kauno kolegijos Medicinos technologijų ir dietetikos katedros mikrobiologijos laboratorijoje, vadovaujantis LST EN ISO 14698-1 plovinių tyrimo standartu. Méginiai buvo paimti plovinių metodu nuo nedezinfekuotų ir dezinfekuotų alginatinių ir silikoninių atspaudų. Ploviniai imti ir nuo dantų technikų pagamintų nedezinfekuotų ir dezinfekuotų protezų (ar kitų gaminių). Tyrimo imtị sudare 24 èminiai mikrobiologiniam tyrimui: 6 nuo nedezinfekuotų, 6 nuo dezinfekuotų dantų atspaudų, 6 nuo

1 lentelè. Nedezinfekuotų ir dezinfekuotų atspaudų mikrobinė tarša.

\begin{tabular}{|c|c|c|c|c|c|c|c|c|c|c|}
\hline \multicolumn{6}{|c|}{ Nedezinfekuotas atspaudas } & \multicolumn{5}{|c|}{ Dezinfekuotas atspaudas } \\
\hline & \begin{tabular}{|c} 
Chro- \\
mogenic \\
Candida \\
Agar \\
\end{tabular} & $\begin{array}{l}\text { Mannitol } \\
\text { Salt Agar }\end{array}$ & \begin{tabular}{|c|} 
Cromogenic \\
Coliform Agar \\
Iso Formu- \\
lation \\
\end{tabular} & $\begin{array}{c}\text { Bile Aes- } \\
\text { culin Azide } \\
\text { Agar }\end{array}$ & $\begin{array}{l}\text { Mueller Hin- } \\
\text { ton Agar II }\end{array}$ & $\begin{array}{c}\text { Chromoge- } \\
\text { nic Candida } \\
\text { Agar }\end{array}$ & $\begin{array}{c}\text { Manni- } \\
\text { tol Salt } \\
\text { Agar }\end{array}$ & $\begin{array}{c}\text { Cromogenic } \\
\text { Coliform } \\
\text { Agar Iso } \\
\text { Formulation } \\
\end{array}$ & \begin{tabular}{|c} 
Bile \\
Aesculin \\
Azide \\
Agar \\
\end{tabular} & $\begin{array}{c}\text { Mueller } \\
\text { Hinton } \\
\text { Agar II }\end{array}$ \\
\hline 1 & - & S. aureus & - & - & $\begin{array}{l}\text { S.mutans, } \\
\text { Veillonella, } \\
\text { Difteroidae }\end{array}$ & - & - & - & - & - \\
\hline 2 & Candida & - & - & $\begin{array}{l}\text { Enterococ- } \\
\text { cus spp. }\end{array}$ & $\begin{array}{l}\text { S.mutans, } \\
\text { Veillonella, } \\
\text { Difteroidae }\end{array}$ & - & - & - & - & - \\
\hline 3 & Candida & $\begin{array}{l}\text { S. saprofi- } \\
\text { ticus }\end{array}$ & - & - & $\begin{array}{l}\text { S.mutans, } \\
\text { Veillonella, } \\
\text { Difteroidae }\end{array}$ & - & - & - & - & - \\
\hline 4 & Candida & $\begin{array}{l}\text { S. saprofi- } \\
\text { ticus }\end{array}$ & - & $\begin{array}{l}\text { Enterococ- } \\
\text { cus spp. }\end{array}$ & $\begin{array}{l}\text { S.mutans, } \\
\text { Veillonella, } \\
\text { Difteroidae }\end{array}$ & - & - & - & - & - \\
\hline 5 & - & $\begin{array}{l}\text { S. saprofi- } \\
\text { ticus }\end{array}$ & - & $\begin{array}{l}\text { Enterococ- } \\
\text { cus spp. }\end{array}$ & $\begin{array}{l}\text { S.mutans, } \\
\text { Veillonella, } \\
\text { Difteroidae }\end{array}$ & - & - & - & - & - \\
\hline 6 & Candida & S. aureus & Coliforms & - & $\begin{array}{l}\text { S.mutans, } \\
\text { Veillonella, } \\
\text { Difteroidae }\end{array}$ & - & - & - & - & - \\
\hline
\end{tabular}


nedezinfekuotų dantų technikų pagamintų protezų (ar kitų gaminių) ir 6 nuo dezinfekuotų dantų technikų pagamintų protezu (ar kitu gaminių). Tyrimo metu paimtuose èminiuose buvo nustatomos 5 analitès: Candida spp, Staphylococcus aureus, Staphylococcus saprophyticus, Streptoccocus spp., Coliform bacteria, Enterococcus spp. ir ịvertinti natūralios burnos mikrofloros mikroorganizmai (Veillonella, Diphtheroids, Streptococcus mutans).

\section{Tyrimo rezultatai ir jų interpretacija}

Atliekant tyrimą siekta nustatyti nedezinfekuotų ir dezinfekuotų dantų atspaudų ir pagamintų dantų protezų (ir kitų gaminių) mikrobinį užterštumą.

Tyrimo metu paimtuose èminiuose buvo nustatomos 5 analitès: Candida spp., Staphylococcus aureus, Staphylococcus saprophyticus, Coliforminès bakterijos, Enterococcus spp. ir ịvertinti burnos natūralios mikrofloros mikroorganizmai (Veillonella, Diphtheroids, Streptococcus mutans).

Atlikus mikrobiologini tyrimą ir pradejjus vertinti dezinfekuotų ir nedezinfekuotų atspaudų ir pagamintų protezų užterštumą, Candida buvo rasta 4 nedezinfekuotuose atspauduose iš 6 (66 proc.), $S$. aureus 2 iš 6 (33 proc.), $S$. saprophyticus 3 iš 6 (50 proc.), Coliforms 1 iš 6 (16 proc.), Enterococcus spp. 3 iš 6 (50 proc.). Natūralios burnos mikrofloros mikroorganizmų (Veillonella, Difteroidae, Streptococcus mutans) buvo rasta visuose 6 nedezinfekuotuose atspauduose (100 proc.). Po atspaudų dezinfekcijos mikroorganizmų neaptikta (1 lentelè). Nedezinfekuotų dantų techniko pagamintų protezų paviršiuje buvo rasta $S$. aureus 5 iš 6 (83 proc.), $S$. saprophyticus 1 iš 6 (16 proc.), Coliform bacteria 3 iš 6 (50 proc.), Enterococcus spp. 3 iš 6 (50 proc.). Po dezinfekcijos pagamintų protezų paviršiuje mikroorganizmų nerasta (2 lentelè).

Nacionalinès visuomenès sveikatos priežiūros laborato- rijos duomenimis, burnos ertmejje esančiu mikroorganizmų skaičius yra antras po storosios žarnos mikrobiotos, mikroorganizmų nuolat randama sveiko žmogaus kūne, burnoje ir tai sudaro jo normalią mikrobiotą. Burnos ertmejje esantys mikroorganizmai dalyvauja maisto metabolizme. Labai svarbi mikrobiotos funkcija yra išlaikyti darbinę ląstelių imuniteto mechanizmų būseną. Burnos mikrobiota pasižymi antagonistiniu poveikiu patogeniniams mikroorganizmams. „Iki šiol dar nèra galutinai išspręstas klausimas dèl bakterijų rūšiu mikrobiocenozėse. Burnos ertmèje rasta 250-280 rūšių bakterijų (îvairių autorių vertinimu), jų grynoji kultūra buvo išskirta, ištirtos jų savybès. Naudojant molekulinius biologinius tyrimų metodus burnos ertmeje, ịvairių autorių duomenimis, buvo rasta 600-750 mikroorganizmų rūšių." [2] Daugiausia bakterijų randama dantų apnašose, o mažiausia - gomurio epitelyje. „Normalus anaerobinių ir aerobinių mikroorganizmų santykis burnos ertmeje yra 10:1. Bakterijos, turinčios anaerobinị kvépavimą, sudaro apie 75 proc. visos bakterinès floros. Kiekybine prasme pagrindinè burnos ertmés mikrobiocenozė yra Streptococcus, Veillonella ir Difteroidae. Likusių bakterijų skaičius burnos ertmejje yra žymiai mažesnis“" [2].

Burnoje yra daugybė mikroorganizmų: bakterijų, grybų ir virusų. Bakterijos yra pagrindiniai burnos gyventojai, jas pirmiausia sudaro Firmicutes, Bacillus, Proteobacteria ir Actinomycetes bakterijos. Žmogaus burnoje galima rasti 85 grybų rūšis. Tarp šių grybų svarbiausias yra Candida, kurie yra neutralūs, kai mikrobiota normali, tačiau pakitus burnos mikrobiotos pusiausvyrai, Candida gali pulti burnos audinius. Candida ir Streptococcus suformuoja bioplèvelę, kuri apsaugo juos nuo išorinių veiksnių, tokių kaip žmogaus imuninès sistemos gynybos ir priešgrybelinių vaistų. Virusai, daugiausia fagai, taip pat yra burnos mikrobiotos dalis. Jie burnos mikrofloroje gyvuoja visais gyvenimo tarpsniais.

2 lentelè. Nedezinfekuotų ir dezinfekuotų pagamintų protezų mikrobinė tarša.

\begin{tabular}{|c|c|c|c|c|c|c|c|c|c|c|}
\hline \multicolumn{6}{|c|}{ Nedezinfekuotas dantų techniko pagamintas protezas } & \multicolumn{5}{|c|}{ Dezinfekuotas dantų techniko pagamintas protezas } \\
\hline $\begin{array}{l}\text { Eil. } \\
\text { Nr. }\end{array}$ & \begin{tabular}{|c|} 
Chro- \\
mogenic \\
Candida \\
Agar \\
\end{tabular} & \begin{tabular}{|l|} 
Mannitol \\
Salt Agar
\end{tabular} & \begin{tabular}{|c|} 
Cromogenic \\
Coliform \\
Agar Iso \\
Formulation \\
\end{tabular} & $\begin{array}{c}\text { Bile Aesculin } \\
\text { Azide Agar }\end{array}$ & $\begin{array}{l}\text { Mueller } \\
\text { Hinton } \\
\text { Agar II }\end{array}$ & $\begin{array}{c}\text { Chro- } \\
\text { mogenic } \\
\text { Candida } \\
\text { Agar } \\
\end{array}$ & $\begin{array}{l}\text { Mannitol } \\
\text { Salt Agar }\end{array}$ & $\begin{array}{c}\text { Cromogenic } \\
\text { Coliform Agar } \\
\text { Iso Formu- } \\
\text { lation }\end{array}$ & $\begin{array}{c}\text { Bile } \\
\text { Aesculin } \\
\text { Azide } \\
\text { Agar }\end{array}$ & $\begin{array}{c}\text { Mueller } \\
\text { Hinton } \\
\text { Agar II }\end{array}$ \\
\hline 1. & - & S. aureus & - & $\begin{array}{l}\text { Enterococcus } \\
\text { spp. }\end{array}$ & - & - & - & - & - & - \\
\hline 2. & - & S. aureus & - & - & - & - & - & - & - & - \\
\hline 3. & - & $\begin{array}{l}\text { S. saprofi- } \\
\text { ticus }\end{array}$ & Coliforms & $\begin{array}{l}\text { Enterococcus } \\
\text { spp. }\end{array}$ & - & - & - & - & - & - \\
\hline 4. & - & S. aureus & Coliforms & $\begin{array}{l}\text { Enterococcus } \\
\text { spp. }\end{array}$ & - & - & - & - & - & - \\
\hline 5. & - & S. aureus & Coliforms & - & - & - & - & - & - & - \\
\hline 6. & - & S. aureus & - & - & - & - & - & - & - & - \\
\hline
\end{tabular}


Kiti virusai gali atsirasti dèl to, kad žmogus turi kitų ligų. Tranzitiniais mikrobiotos virusais gali būti kiaulytès virusas ir ŽIV, herpeso virusai. Iprastos ir dažniausiai randamos burnos bakterijos yra Streptococcus mutans, Porphyromonas gingivalis, Staphylococcus ir Lactobacillus [5].

Dauguma infekcinių ligų sukèlëjų plinta per nešvarias rankas. Rankos nuolat kontaktuoja su mikrobais, esančiais ant aplinkos objektų, liečiamų paviršių, naminių gyvūnèlių ir kt. Sveikatos priežiūros darbuotojai kiekvieną dieną kontaktuoja su žmonėmis, kurie gali savo nosiaryklès gleivinejje, odoje, ant rankų, drabužių nešioti įvairius mikroorganizmus. Dèl kontakto su pacientais padidejja infekcijų plitimo tikimybè, todèl labai svarbu tinkamai prižiūrèti darbo aplinkos objektus, apruošti instrumentus, įrankius, su kuriais atliekamos intervencijos ir laikytis rankų higienos reikalavimų. Mūvèti vienkartines pirštines, naudoti apsaugines kaukes, akinius arba skydelius.

Nesilaikant rankų higienos, dažniausiai plinta žarnyno natūralios mikrobiotos atstovai stafilokokai. Rankų higiena yra bendras terminas, taikomas rankų plovimui, antiseptiniam rankų plovimui, antiseptiniam rankų apruošimui arba chirurginei rankų antiseptikai. Ligų kontrolès ir prevencijos centras (CDC) apibrèžia šią veiklą taip: rankų plovimas - tai, kai rankos plaunamos paprastu (t. y. antimikrobiniu) muilu ir vandeniu. Rankų antiseptikas reiškia antiseptinį rankų plovimą arba antiseptinį rankų trynimą. Chirurginis rankų antiseptikas - antiseptinis rankų plovimas ar antiseptinis rankų apruošimas, kurị chirurginis personalas atlieka prieš operaciją, kad pašalintų mikroorganizmus ir sumažintų rankų florą.

„Gera rankų higiena yra svarbus aspektas, apsaugant save ir kitus nuo infekcijos perdavimo. Tai yra vienas iš efektyviausių būdų užkirsti kelią su ligoninès priežiūra susijusiems infekcijų rodikliams. Tinkamos rankų higienos nesilaikymas laikomas pagrindine su sveikatos priežiūra susijusių infekcijų ir daugelio atsparių organizmų, tokių kaip meticilinui atsparus Staphylococcus Aureus (MRSA), plitimo priežastimi, kuris pripažintas esminiu hospitalinių infekcijų sukèlejju“ [8].

Rankų plovimas muilu ir vandeniu daugeliu atvejų yra geriausias būdas pašalinti mikrobus. Jei muilo ir vandens nèra, galima naudoti alkoholio pagrindo rankų dezinfekavimo priemones, gelį, dezinfekuojamąsias servetèles, purškiamą dezinfekantą, kuriame yra ne mažiau kaip 60 proc. alkoholio. Šios dezinfekavimo priemonès yra efektyviausi agentai, mažinantys bakterijų ir virusų skaičių ant rankų. Švarios rankos yra paprastas ir veiksmingas būdas sumažinti infekcijų plitimą nuo vieno žmogaus kitam ir visoje bendruomenėje - nuo jūsų namų ir darbo iki vaikų priežiūros istaigų ir ligoninių [4].

Tyrimo metu buvo galimybė įrodyti bakterinę ir grybinę taršą, tačiau tuo pačiu būdu (per nedezinfekuotus atspaudus ir nedezinfekuotus gaminius) plinta virusinès ligos su burnos biologiniais skysčiais - tymai, kiaulytè, Herpes virusas, Covid, gripas ir kt. Per kraują plinta hepatitas B, C, D (HBV, HCV, HDV) ir ŽIV. Šie virusai gali plisti tiesioginio kontakto (lytiniu) būdu. Pagrindinis apsisaugojimo būdas yra dezinfekcija. Dantų technikui labai svarbu darbą pradèti nuo švaraus - dezinfekuoto atspaudo. Privalu laikytis higienos normos HN 47-1:2020, kuri nurodo, kaip teisingai atlikti dezinfekciją ir sukurti saugią darbo aplinką.

\section{Išvados}

1. Apibendrinus mokslinę literatūrą galima teigti, kad aplink mus gyvuoja plika akimi nematomas gyvų mikroorganizmų pasaulis, kuriame galima rasti bakterijų, virusų, grybų, pirmuonių. Mikroorganizmai gali būti žmogaus ir aplinkos natūralios mikrobiotos dalis ir sukeliantys ịvairias infekcines ligas. Žmogaus burnoje gausu mikroorganizmų, vieni iš jų nuolat gyvena burnos ertmejje, o kiti yra tranzitiniai ir ị burnos ertmę patenka iš aplinkos, per nešvarias rankas, oro lašelių būdu, su maistu. Burnos ertmèje galima aptikti Streptococcus mutans, Fusobacterium nucleatum, Porphyromonas gingivalis, Streptococcus pyogenes, Veillonella, Difteroidai, Candida, S. aureus, Streptococcus pyogenes, Spirochaetes, virusų ir daug kitų mikroorganizmų. Kiekvienas mikroorganizmas turi savo genomą, morfologiją, fiziologiją, biochemines savybes, pagal kurias jie indentifikuojami.

2. Nedezinfekuotų dantų atspaudų paviršiuje aptikta natūralios burnos mikrofloros atstovų S.mutans, Veillonella, Difteroids. Nedezinfekuotu pagamintų dantų protezu paviršiuje rasta Enterococcus spp., S.mutans, Veillonella, Difteroids, S. aureus, S. saprofiticus, Coliforms. Aptikta Enteroccocus spp. ir koliforminių bakterijų. Ant nedezinfekuotu gaminių aptikti mikroorganizmai rodo, kad dantų technikai nesilaiko tinkamos rankų higienos, nes ant pagamintų dantų protezų pateko žarnyno mikrofloros atstovų, S.aureus. Po dezinfekcijos mikrobinè tarša ant atspaudų sumažejo, tačiau iš tranzitinių mikroorganizmų dviejų pagamintų protezu paviršiuje liko žarnyno mikrobiotos atstovų (coliforminių bakterijų ir S.aureus), todèl galima teigti, kad buvo nepakankama dezinfekcija.

3. Nedezinfekuotuose atspauduose buvo rasta $S$. aureus, Candida, S. saprofiticus, Enterococcus spp., Coliforms, (S.mutans, Veillonella, Difteroids) natūralios burnos mikrofloros atstovai. Po dezinfekcijos mikrobų neaptikta. Tai rodo dezinfekcijos būtinumą, įrodo, kad pagrindinis veiksnys, naikinantis mikrobinę taršą, yra dezinfekcija. Prieš dezinfekciją ant pagamintų dantų protezų buvo rasta $S$. aureus, $S$. saprofiticus, Coliforms, Enterococcus spp, o po dezinfekcijos buvo rasta S. Epidermis, S. aureus, Coliforms, Enterococcus. 


\section{Literatūra}

1. Lietuvos Respublikos sveikatos apsaugos ministro $2020 \mathrm{~m}$. gruodžio 10 d. ísakymas Nr. V-2877 Dėl Lietuvos Respublikos sveikatos apsaugos ministro $2012 \mathrm{~m}$. spalio $19 \mathrm{~d}$. įsakymo Nr . V-946, „Dèl Lietuvos Higienos normos HN 47-1:2012 „Sveikatos priežiūros įstaigos. Infekcijų kontrolès reikalavimai“ patvirtinimo" pakeitimo.TAR, 2020-12-10, Nr. 26932.

2. Nacionalinè visuomenès sveikatos priežiūros laboratorija. Burnos mikroflora - pradinè natūralios virškinamojo trakto mikrofloros apsauginès funkcijos grandis. Parengè R. Jankauskienè, 2020. http://www.nvspl.1t/popup2.php?m_news $\mathrm{id}=482 \&$ tmpl_name $=\mathrm{m} \_$news_print_form

3. Chapple ILC, Mealey BL, Van Dyke TE, Bartold PM, Dommisch H, Eickholz P, Geisinger ML, Genco RJ, Glogauer M, Goldstein M, Griffin TJ, Holmstrup P, Johnson GK, Kapila Y, Lang NP, Meyle J, Murakami S, Plemons J, Romito G A, Shapira L, Tatakis DN, Teughels W, Trombelli L, Walter C, Wimmer G, Xenoudi P, Yoshie H. Periodontal health and gingival diseases and conditions on an intact and a reduced periodontium: Consensus report of workgroup 1 of the 2017 World Workshop on the Classification of Periodontal and Peri-Implant Diseases and Conditions. J Periodontol 2018;89 Suppl 1:S74-S84. https://doi.org/10.1002/JPER.17-0719

4. Sahoo PK, Priyadarshini SR, Choudhury G, Pati AR, Mohapatra A. Hand Hygiene an Important Need in Daily Practice. Indian Journal of Public Health Research Development 2018; 9(12):2441-2444. https://doi.org/10.5958/0976-5506.2018.02134.4

5. Mushtaq MA, Khan MWU. An Overview of Dental Impression Disinfection Techniques-A Literature Review. J Pak Dent Assoc 2018;27(4):207-12. https://doi.org/10.25301/JPDA.274.207

6. Cavalheiro M, Teixeira MC. Candida Biofilms: Threats, Challenges, and Promising Strategies. Frontiers in Medicin 2018. https://doi.org/10.3389/fmed.2018.00028

7. Mortadi NAl, Al-Khatib A, Alzoubi KH, Khabour OF. Disinfection of dental impressions: knowledge and practice among dental technicians. Clin Cosmet Investig Dent 2019;11:103-108 https://doi.org/10.2147/CCIDE.S205144

8. Hand Hygiene. Physiopedia.

https://www.physio-pedia.com/Hand_Hygiene

\section{INFLUENCE OF DISINFECTION ON MICROBIAL CONTAMINATION OF DENTAL IMPRESSIONS AND MANUFACTURED DENTURES}

E. Pliuščikaitė, A. Vaičiulevičienė, I. Vasilavičiūtė, D. Mačiulienè

Keywords: impression, prosthesis, disinfection, microorganism, bacteria, microbial contamination.

\section{Summary}

In today's world, there are countless diseases and even more chances of contracting them. Every day we are exposed to various bacteria and pathogens that are dangerous to the human body and can cause disease. Bacteria and microorganisms not only exist in the human environment and in the household, some pathogens live in the human body. Man does not avoid daily contact with microorganisms that come from the environment on clothes, hands, skin, hair, no exceptions and the oral cavity. The state of oral contamination is determined not only by environmental factors, but also by personal and oral hygiene, heredity, and general health. Due to poor oral hygiene, the amount of bacteria and microorganisms increases uncontrollably - this can lead to bad breath, loss of aesthetics, yellowish or even brown teeth, as well as the formation of soft plaque, which eventually becomes hard plaque (stones). Without visiting a specialist and without removing the plaque, the gums start to bleed, which is the first sign of gingivitis - gingivitis, in the long run it develops into periodontitis and eventually into paradantosis, which leads to tooth loss. Paradantosis is caused by a variety of bacteria that accumulate in dental plaque and hard stones. Alginate or silicone prints are used when planning prosthetics. Microorganisms that are found in a patient's mouth can contaminate the impression, which is the primary and main object used by dental technicians to make dentures, etc. Once the impressions are removed and disinfected, the microorganisms from the patient's mouth will fall on the dentist's hands (gloves). The saliva-infected uninfected impression travels to the dental technician's lab, and then the uninfected impression returns contaminated with microorganisms from the dental technician's hands. This results in a chain of cross-contamination and the spread of microorganisms in the environment. The dentist often works with assistants, sometimes requiring the services of an anesthesiologist during surgery, which increases the risk of the microorganisms spreading and becoming infected. Likewise, the risk of infection remains in the laboratory of dental technicians. Once uninfected prints enter the dental technology laboratory, microorganisms can spread on the work surface, work tools, dental technician's hands.

Correspondence to: emile.plius@gmail.com

Gauta 2021-10-04 